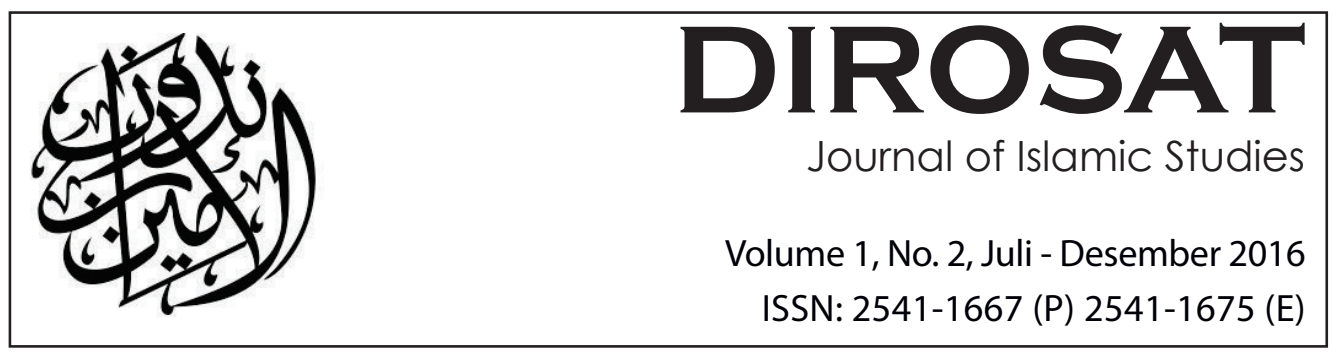

\title{
Muslim World and the Globalisation Challenge: [En]Countering Dehumanization or Humanised Integrationi*
}

\section{Azhar Ibrahim}

Department of Malay Studies

National University of Singapore

Abstrak: Globalisasi adalah tantangan sekaligus peluang bagi dunia Muslim. Istilah globalisasi saat inilebih banyak dipahami untuk membuka pasar seluasluasnya bagi korporasi transnasional yang secara jelas mendorong liberalisasi ekonomi. Hal ini sangat ironis bagi mereka (negara-negara) yang mengajak agar "membuka batas-batas" atau "liberalisasi kapital" ternyata merupakan pihak yang sangat ketat dalam memberlakukan praktik dan kebijakan imigrasi. Pihak ini melakukan proteksi terhadap pasar tenaga kerja mereka sendiri, sementara mendorong dan mengoptimalkan keberadaan korporasi transnasional yang mereka miliki untuk menguasai pasar di negara-negara

This paper is presented at International Conference, "MUSLIMS' FUTURE: GLOBALIZATION OPPORTUNITY AND CHALLENGE," at Al-Amien Prenduan Boarding School, Madura, Indonesia on $8^{\text {th }}$ Nov 2016. 
berkembang. Fakta tersebut merupakan kontradiksi yang sangat tampak mencolok. Padahal efek-efek globalisasi neoliberal yang membahayakan bisa menyerang berbagai aspek kehidupan manusia yang paling krusial, seperti keadilan ekonomi, kondisi lingkungan, dan sistem pendidikan. Oleh karena itu, tanggapan kritis terhadap globalisasi perlu dilakukan. Dalam berbagai hal, kesediaan untuk mendiskusikan globalisasi secara kritis sangat-sangat diharapkan. Naskah ini menunjukkan tentang pentingnya diskusi mengenai globalisasi di luar aspek-aspek ekonominya belaka. Di dalamnya terdapat tawaran untuk menciptakan dan memproyeksikan bentuk lain globalisasi yang memanusiakan integrasi global. Peluang nyata yang tampak ini bisa diraih ketika kita mampu melihat masalah-masalah kemanusiaan secara utuh. Di sinilah umat Muslim perlu menunjukkan posisinya di garda terdepan dalam membentuk solidaritas dan kerja sama kemanusiaan sehingga dapat mencapai tujuan tatanan global yang manusiawi.

Kata Kunci: globalisasi, korporasi transnasional, globalisasi yang manusiawi, solidaritas, kerja sama

Abstract: Globalisation is a challenge for Muslim world as it can be opportunities. The term globalisation mostly refers to the opening up the market to transnational corporations (TNCs) which is in line with liberalisation of the economy. Ironically those who call for "opening up of borders" or "capital liberalisation" are actually the one who are so strict in the immigration policies and practices. Protecting their own labour market, while encouraging their own TNCs to optimise their presence in the developing countries is a blatant contradiction. The calamitous effects of neoliberal globalisation are striking crucial aspects of life, such as economic justice, environmental condition, and educational system. Therefore, critical response to globalisation is imperative. In many ways, the readiness to discuss critically on globalisation is very much to be welcomed. This paper points to the need to discuss beyond the preoccupation of economic needs. It proposes to create and project another kind of globalisation which points to a humanised global integration. The real opportunity is when we are able to see the problems of humankind as a whole. Muslim must be at the forefront in forging human solidarity and cooperation so as to attain a humanised global order.

Keywords: globalisation, transnational corporations, humanised globalisation, solidarity, cooperation. 
"the earth will have to be understood as inescapably interconnected. For living with the planet, sharing -while being respectful of true singularization -is our only choice. And the world, the globe, the universe, and all living things must constitute the base of our studies and investigations, in fact, of our consciousness itself. The university-and the world that contains it -could be a happier place, if it were organised around this idea of planetary commonality and totality."

Masao Miyoshi

lobalisation is indeed a challenge inasmuch it can be opportunities. Its meaning can be so diverse depending on the groups and interests that are behind it. Technically the term globalisation, which is commonly uttered today, refers to the opening up the market to transnational corporations, where free trade and liberalisation of the economy becomes its fundamental creed. In the words of Arif Dirlik: "If globalization means anything, it is the incorporation of societies globally into a capitalist modernity, with all the implications of the latter - economic, social, political, and cultural." ${ }^{2}$ Globalisation is indeed the catch phrase of today, much of it celebrates the "global village" and "global outlook" which is more or less the world become closer via economic interdependence.

While today's globalisation is celebrated as modern and cosmopolitan with progressive outlook, there is rarely a consistent and penetrating scrutiny or rethinking of the idea. While the leftist call for internationalism for the worldwide solidarity of the working class against the parasitic elements in society has been simply dismissed as a disastrous leftist model, today's globalisation pose itself as a benign agenda that aim to uplift and opening up all the economies in this planet. Thus it is not uncommon that this globalisation is celebrated as the "Way to move forward", even hailing it as the postmodern or postcolonial world that we are entering, with a caveat: for those who are not being able to embrace it, they will be left behind.

$2 \quad$ Arif Drilik, "The End of Colonialism? The Colonial Modern in the Making of Global Modernity," (Boundary 2, 32:1, 2005), 4. 
Globalisation becomes the mantra to celebrate and embrace the market system. In the mass media, education, arts and culture, globalisation has become a savvy catchphrase. Ironically those who call for "opening up of borders" or "capital liberalisation" are actually the one who are so strict in the immigration policies and practices. Protecting their own labour market, while encouraging their own TNCs to optimise their presence in the developing countries, with various labour abuses, is a blatant contradiction. Trade protectionism is erected by developed economies while pressuring others to open up their economy. The market and corporate moghul wants an open globalised border for their capital and profit interest.

Those who are not global would be seen as parochial, insular, backward and the like. In this dominant conception there is hardly any space for an idiom or imagination for discursive scrutiny to emerge. Thus it is not uncommon that the discourse points the need to embrace and reap its opportunities than to seriously and critically reflect on the many discrepancies and problems of the present world order.

Critical scholarships have shown how globalisation has undermined the South (developing countries) attempts to free themselves from the clutches of dependency. Even societies in developed economies are not spared. While many celebrated the promises and potentials of globalisation, some other critical voices have highlighted the monstrosity of the market driven globalisation, where the very effect is on the existential wellbeing of the individual and society. As deliberated below, echoing some of the strongest critiques on globalisation itself:

"The market requires the brutalization and destruction of the sense of community: the transmutation of living spaces- cities, streets, houses-earth, water, air, bodies, people, work, and life into goods and the taking away of individual and populations characteristics that serve to realize and complete any project compatible with a human vocation that is not mechanization. The market ideology demands the "objectifications" of the people, who are to be treated as disposable objects easily replaced, which in turn facilitates their exploitation as labour that is increasingly devalued. This ideological stance requires a maximum of ephemeral human relations, fragile and poorly conducted, and always places suspicion on movements and forms of union that can become the seeds of trouble some questions. The strengthening 
of this ideology needs to devalue and disrespect life. This devaluation and disrespect culminate in the disregard for other human beings evident in the violence plaguing the planet like as epidemic of horrific proportions. Another side effect is the disregard for other living beings and nature in general, both of which are now also perceived as "economic resources," thus an anthropocentrism that is leading to the destruction of the environment and of life itself." ${ }^{\prime \prime}$

To date, our cultural and intellectual response to globalisation, especially the critical ones have been sparse and intermittent. ${ }^{4}$ Some of the valid questions that we need to pose are: (a) what are some of the real motives/ interest in the propagation of globalisation that we commonly heard today; and (b) therefore it is important to ask Who is behind the call for globalisation? and (c) whose agenda and interest that globalisation truly serving? In many ways, the readiness to discuss critically on globalisation is very much to be welcomed, especially in the context where we have a certain preoccupation the internal or national issues at length but divorced from the larger context of the globalised order, with an assumption that the latter bears no direct bearing on what is happening at home.

\section{The Fervour to Globalise}

At present the obsession to be "global" is not uncommon in many societies. Interestingly, the term global has certain projection of haughtiness, as being global and international would refer to the metropolitan centers of the Western hemisphere, and obviously not referring to our own national and regional ones, even though there are no less from the "foreign" ones in terms of standard, quality and depth. The mood and celebration for globalisation, which means to attain a kind of international standard, excellence and recognition, have

3 Walter Ferreira de Oliveira, "For a Pedagogy of Solidarity," in Paulo Freire, Pedagogy of Solidarity. (California: Left Coast Press, 2014), 74.

4 Amongst Indonesian Muslim writers who dealt with this issue: Mansour Fakih, Jalan Lain: Manifesto Intelektual Organik. (Yogyakarta: Pustaka Pelajar, 2011) ; Sritua Arief, Negeri Terjajah: Menyingkap Ilusi Kemerdekaan. (Yogyakarta: Resist Book, 2006); Galih Prasetyo, Indonesia dalam Cengkraman Liberalisme: Krisis, IMF dan Jalan Pemulian Ekonomi. Jakarta: Penerbit Koekoesan, 2015 ; Eko Prasetyo, Islam Kiri:Jalan Menuju Revolusi Sosial. (Yogyakarta: Insist Press, 2004) 
become a commonplace. In other words, the fervour to globalise is deemed as natural in an era of competition, ranking and international standing.

Not surprisingly to be global means having an international reputation and recognition, and often that recognition is based on the yardstick as formulated in the West. Today we see a great excitement to attain such position ranging from "global village" and "global citizens", to "global university" and "global culture", including "global city" and "global studies." To be global itself could mean a series of meaning such as "international", "universal," and other syndrome of the traits of modern, cosmopolitan, liberal with not just the outlook, but lifestyle of globetrotting savviness.

\section{The Globalisation Idea asManufactured Consent}

Even the present idea of globalisation has usurped our imagination of what it means to be "global", that is primarily in the economic dimension. However, there are other global movements today in this world, which we rarely have given exposure or attention to. In fact, we have no alternative language, not only to criticise the dominant neoliberal globalisation but also to imagine another form of globalisation that is based on solidarity, equality and common humanity. We have generally accepted the term globalisation as something given, natural and warranted. We must ride on it unless we are ready to be left behind, at our own peril.

The globalisation that is on-going and justified in its neoliberal schema of things will cause eventually the ( a ) weakening national economy that is subjected to market and financial volatility; ( $b$ ) opening of the market only to benefit those transnational corporations and developed economies; ( c ) an economy that is still unable to go beyond its status as supplier cheap labour and the reading market for exports from developed economies; $(\mathrm{d})$ subsidies and tax cuts favouring transnational corporations and its local compradors at the expense of safeguarding the welfare of the citizens. As Wim Dierckxsenspoints out: "extreme neoliberalism results in a society where only the 'fittest' have a 
real right to life. The legitimacy of this survival of the fittest prevails as society becomes society becomes more exclusionary." ${ }^{5}$

\section{Opposing Neoliberal Globalisation}

If globalisation means securing the opportunities for neoliberal market to expand and extend its wings, then we have many reasons to reject it. If globalisation means neo-imperialism, the present arrangement of globalisation that are operating now, would spell for an imminent crisis, where the present dehumanised condition presents a real threat to humanity.The calamitous effects of neoliberal globalization, in the words of Masao Miyoshi, are "one, the ever widening gulf in the distribution of wealth and power; two, the environmental catastrophe that is about to visit the planet or is already here; and three, the transformation of the university as a learning place into a corporate system, and of learning into intellectual property and entertainment. “6

The neoliberal globalisation has tremendous grave effects on developing societies. The rapacious side of TNCs'( transnational corporations) domination is destructive and dehumanising. Farmers lost their lands as speculative property market encroached productive land; factory workers easily retrenched as factories transfer to another country of cheaper labour cost, and many other detrimental effects, including its effects on human culture and the natural environment:

"...the radical alteration of human habitats means the destruction of local and regional culture. Furthermore, the maximum profit principle does not hesitate to destroy the everyday life of local society if it does not willingly convert itself into an attractive commodity. Even officially "traditional" artifacts-music, poetry, arts-are tested on their marketability, and all folk and ceremonial products and performances are similarly examined. "Traditional" arts and forms are fragmented and decontextualized so as to be staged, museumized, collected, or merchandised. Even local resistance and nativist

5 Wim Dierckxsens, The Limits of Capitalism: An Approach to Globalization without Neoliberalism. (London: Zed Books, 2000), 151.

6 Masao Miyoshi, "The University, the Universe, the World, and "Globalization," (The Global South, Vol. 1, 1, 2007), 29. 
resentment are open to the seduction of consumerism as can be seen in the history of graffiti art and rap music. New meanings are attached to all cultural products through aestheticization and/or pricing. Tourism and entertainment seem to be the triumphalist destination of all, and local, national, and regional differences are always on the verge of reduction to mere variants in the universal theme park, which is informed with the TNC worldview."7

In other words, it is extremely naïve for those who want to call for embracing globalisation if they have no inkling or interest to lay bare the monstrosity of neoliberalism. The latter noted Chomsky: "undermine education and health, increase inequality, and reduce labor's share in income." We therefore cannot be blinded by the enticement of neo-liberal outlook that promises a global world where the free market will the mechanism to balance and meet the human needs in the best manner ( namely 'efficient', 'productive' and 'rational' ). But before we can criticised it, we need to understand its mechanics of causes and the effects of this order. Hence globalisation is not simply to be celebrated, but must be contested.

Globalisation with a humanistic face and spirit is one that should be welcomed and affirmed. In other words, we must be able to make distinction between the globalisation that generated by the interest of market and corporate forces, as opposed to the humanistic sentiment in securing the welfare and interest of the larger humanity. Conversely if globalisation is to justify the aggrandizement of empire builders, then we have to reject it? If it is hegemonic or serving only the interest of the privileged few, then it must be subjected to scrutiny. This is exactly the problems that few thinkers and scholars have deliberated at length which deserve our attention.

\section{Let's Embrace Globalisation!}

Indeed there is a correlation between the supporters of neoliberalism and the promoters of globalisation. Generally, the opening up of the local economy to the international players is made in the name of expanding and enhancing

7 Masao Miyoshi, "Sites of Resistance in the Global Economy," (Boundary 2, 22:1, 1995), 69.

8 Noam Chomsky, Profit Over People: Neoliberalism and Global Order. (New York: Seven Stories Press, 1999), 32. 
the rate of development for developing countries, or liberalising the economy in order to attract foreign investment.

"Many in the Third World misinterpret or are suspicious of globalization because of its Western, in particular American, origin. Since the West once colonized many Third World countries, this fear is understandable... ugly underlying racist assumption - distrust of the White man. Why should we reject ideas simply because they originate from other than one's own kind? This is not rational. We should be able to evaluate the merits of globalization regardless of its promoters and or origin...If Malaysians can better understand globalization, they can use its full advantage. It is the ticket for Malaysia to join the ranks of the developed world and to achieve its Vision 2020 aspirations. The way forward for Malaysia is not to rant and rave against globalization, rather to accept it and seize the opportunities afforded."9

Such view is actually not uncommon. The assumption is that we must move ahead and take the economic opportunities offered by globalisation, and our failure to do that will be detrimental for our own wellbeing. Interestingly too, there are many academic discussions about it that treats it like a research topic with all its intricate typologies, description and theoretical models used in analysing globalisation but lacks the critical position to reject the dehumanised form of globalisation..$^{10}$

\section{Critical Responses to globalisation}

Generally, the responses to globalisation have been diverse, but a general acceptance of its inevitability is common. This in turn paralysing our options and alternatives, as we come to think that best way to go with is affirming globalisation, reaping its opportunities and avert its undesirability. An Indonesian scholar, who has written several works criticizing the neoliberal paradigm as adopted in the Indonesian economic policy, noted that leading Indonesian economists have been too impressed by globalisation. To him this is dangerous:

9 M Bakri Musa, Malaysia in the Era of Globalization. (San Jose: Writers Club Press, 2002), 146-147

10 See for instance, Rosazman Hussin et al. Globalisasi: Beberapa Pendekatan Sains Sosial. (Kuala Lumpur: DBP, 2001). 
"Keterpesonaan yang berlebihan terhadap globalisasi itu tentu sangat berbahaya bagi masa depan perekonomian rakyat, ketahanan ekonomi nasional, dan bahkan bagi keutuhan Indonesia sebagai sebuah bangsa."”

Some Indonesian Muslims thinkers have reflected critically on the effects of globalisation. In Indonesia two prominent scholars, namely Mansour Fakih and Abdurahman Wahid have highlighted the challenges of globalisation. Mansour is especially critical of the threat of globalisation, tracing it to the problematic promises of neoliberalism and the dominant ideas of development. He reminds that globalisation that is embraced and affirmed only brings benefits to TNCs

"Proses globalisasi ditandai dengan pesatnya perkembangan paham kapitalisme, yakni kian terbuka dan globalnya peran pasar, investasi, dan proses produksi dari perusahaan-perusahaan transnasional, yang kemudian dikuatkan oleh ideologi dan tata dunia perdagangan baru di bawah suatu aturan yang ditetapkan oleh organisasi perdagangan bebas secara global....." ${ }^{{ }^{2}}$

While the TNCs accumulated its profits, those in the margin with adversely affected, ( like small scale entrepreneurs ) while governments regulating national policies favouring TNC's at the expense of the people's interests, through subsidies, tax relief and preferential credit treatment.

"bersamaan dengan pesatnya kemajuan globalisasi dari tingkat internasional hingga tingkat lokal, berbagai korban, terutama masyarakat adat, kaum miskin kota, dan golongan marjinal lainnya telah mulai dirasakan. Meskipun hampir semua pemerintah menerima globalisasi dan mulai melakukan penyesuaian kebijakan, dan undang-undangan dalam negeri disesuaian dengan kebijakan yang disepakati dalam aturan global menyangkut soal investasi, hambatan perdagangan, pertanian dan pertanahan, pajak, hak paten dan lain sebagainya, namun sesungguhnya rakyat di masing-masing negara tersebut belum tentu sepenuhnya menerima globalisasi. ${ }^{{ }^{13}}$

Elsewhere Mansour noted, while the globalisation only favours the TNCs whose interest in accumulating capital at the global scale, its disastrous effects

\footnotetext{
11 Revrisond Baswir, Bahaya Neoliberalisme. (Yogjakarta: Pustaka Pelajar, 2009), 42.

12 Mansour Fakih, Runtuhnya Teori Pembangunan dan Globalisasi. (Yogjakarta: Pustaka Pelajar \& Insist Press, 2008), 198.

13 Ibid., 223.
} 
on the nature, culture and humanity as a whole. The wretched poor will be the most adversely affected:

"Globalisasi, serta berbagai proyek kapitalisme yang lain bagi golongan ini menjadi salah satu penyebab yang memiskinkan, memarginalisasi dan mengalienasi masyarakat. Selain melalui usaha praktis untuk membantu memecahkan persoalan ekonomi, politik dan budaya keseharian melalui proyek-proyek pengembangan ekonomi yang berbasis masyarakat, juga usaha praktis tersebut dikaitkan dengan melakukan advokasi untuk mempengaruhi segenap kebijakan negara yang memarginalkan kaum miskin dan pinggiran. Oleh karena itu bagi mereka pengembangan masyarakat selalu berdimensi politik.Globalisasi justru bagi golongan ini secara fundamental adalah ancaman bagi orang miskin."14

Similarly an Indonesian cultural critic, Radhar Panca Dahana spoke of the debilitating effects of neoliberal globalisation on the cultural realms

"Pihak yang paling teruntungkan dari globalisasi kebudayaan seperti ini tidak lain adalah mereka yang memiliki ambisi kuasa dan ambisi ekonomi di tingkat dunia, para pemilik modal global khususnya. Hidup yang "segera" adalah hidup yang tak membiarkan kita berpikir tenang untuk menetapkan pilihan atau membuat keputusan.Pada tingkat konsumsi, psiko-massa semacam ini membuat kita dengan cepat memutuskan untuk mengkonsumsi atau membeli sesuatu, tanpa pertimbangan panjang, hanya merek dan propaganda yang jadi pegangan.Tingkat konsumsi semacam itulah yang membuat produksi semakin gencar.Gaya hidup yang modis dan fashionable membuat kita harus terus berganti barang-barang kebutuhan kita, begitu mode atau fashion baru diciptakan.Bahkan, untuk barang yang semula berdurasi tahunan atau puluhan tahun pun kini harus berganti tiap bulan/ tahun, mulai dari busana, telepon selular, alat-alat elektronik, kendaraan, bahkan rumah. ${ }^{" 15}$

In all, as globalisation conditions our social formation and economic development we need to thoroughly scrutinise its workings and effects. But criticising alone is not enough. We need to imagine another globalised order

14 Mansour Fakih, "Islam sebagai Alternatif," dlm Eko Prasetyo, Islam Kiri Melawan Kapitalisme Modal dari Wacana Menuju Gerakan. (Yogyakarta: Pustaka Pelajar \& Insist Press, 2002), xvii.

15 Radhar Panca Dahana, Ekonomi Cukup: Kritik Budaya pada Kapitalisme. (Jakarta: Kompas, 2015), 112. 
that is marked by a sense of greater solidarity and humanity. A point made by Mansour Fakih:

"Belajar dari perjalanan formasi sosial yang pernah diterapkan sejak formasi sosial kolonialisme menuju formasi sosial developmentalisme dan kini menuju formasi sosial globalisasi kapitalisme, maka perubahan sosial di masa mendatang perlu ditegakkan di atas prinsip-prinsip yang tidak mengabaikan perkembangan kemanusiaan secara utuh, yang memiliki sensitivitas kultural terhadap kelompok-kelompok minoritas, serta perubahan sosial yang memberi ruang bagi penentuan nasib sendiri bagi kaum marjinal. Perubahan sosial di masa mendatang haruslah menghormati kedaulatan bangsa dan rakyat, serta suatu proses sosial yang dibangun di atas sensitivitas gender, ekologi yang sustainable serta penghormatan atas hak-hak azasi manusia baik hak-hak sipil politik maupun hak-hak sosial ekonomi dan budaya. Kesemuanya dilandaskan pada keadilan sosial bagi semua dan transformasi relasi antar semua entitas dalam masyarakat menuju keadaan yang lebih adil. ${ }^{n 6}$

Our ethical -religious bearings demand us to reject any kind of exploitation. Here the globalisation accentuated the market driven economy with its "selected" laisses faire precepts. According to Gus Dur, the Islamic notion of upholding justice and averting exploitation must be the basic foundation in our dealings with this neoliberal market order. While our religion enjoins profit seeking in economic transaction, it never condones an exploitative one:

"Dengan pendekatan non-eksploitatif semacam itu, memang tidak dibenarkan adanya perkembangan pasar tanpa campur tangan pemerintah, minimal untuk mencegah terjadinya eksploitasi itu sendiri. Di sinilah peranan negara menjadi sangat penting, yaitu menjamin agar tidak ada manusia/ warga negara yang terhimpit oleh sebuah transaksi ekonomi. Manusia harus diutamakan dari mekanisme pasar dan bukan sebaliknya. Jika prinsip non-eksploitatif dalam sebuah transaksi ekonomi seperti digambarkan di atas terjadi, maka dengan sendirinya pengertian akan globalisasi juga harus dijauhkan dari dominasi sebuah negara/perusahaan atas negara/ perusahaan lain. Karena itu, globalisasi dalam pengertian lama yang hanya mementingkan satu pihak saja haruslah dirubah dengan pengertian baru

16 Mansour Fakih, Runtuhnya Teori Pembangunan dan Globalisasi, p. 231 
yang lebih menekankan keseimbangan antara pemakai/pengguna sebuah barang/jasa dan penghasil (produsennya). ${ }^{{ }^{\prime 17}}$

Gus Dur's criticism puts the point across rather simple. Any economic regime that allows for exploitation must be rejected, if not corrected. Indeed a leading Indonesian economist, who is very critical of the present economic regime, pointed out the importance of religious leaders in promoting economic equality. ${ }^{18}$ But this is not to be confused with the increasing enthusiasm amongst some quarters that call for the implementation of Islamic Economics, which in many ways have similar structures with the present capitalist model. Interestingly to note that in the case of Indonesia, the enthusiasm and anxieties over the promises of globalisation, has direct impact on the discourse of Ekonomi Pancasila or Ekonomi Kerakyatan, to a point of relegating them as utopianistic or simply infested by the outworn socialistic paradigm.

While some other groups (including religious ones) taking a critical position against globalisation, there are some amongst Muslim writers who suddenly make claims that globalisation as a process has already being initiated or even pioneered by Islam. Muslims are enjoined to reap the opportunities offered by contemporary globalisation. Such thinking obviously missed the point. Also, as we can easily observe that the neoliberal globalisation and development issues are hardly given critical scrutiny by the religious circles, in comparison to the current interest inIslamising theconventional economic system, particularly the banking sector.

In other words, Muslim societies all around the world cannot be simply celebrating this type of globalisation that is unjust and inhumane. Globalisation of the neoliberal market system benefit the few, enriching already the wealthy ones, accentuating the great income disparity between the rich and poor, and the worsening working conditions of those in the lower economic rung. It is in this sense that the poor, especially in Muslim societies, are in need of an

17 "Islam dan Globalisasi Ekonomi" in Abdurrahman Wahid, Islamku, Islam Anda, Islam Kita. (Jakarta: The Wahid Institute, 2006), 190.

18 Mubyarto: Tokoh agama Memgang Peranan Sangat Penting Untuk Realisasi Program-program Pemerataan," in Tarli Nugroho, Polemik Ekonomi Pancasila. (Yogyakarta: Mubyarto Institute, 2016). 
effective mechanism to counter this dehumanising grip, with the ability to link their plight as part of this global predicament. ${ }^{19}$

\section{Is Globalisation for Universalism?}

In this era of convoluted thought, with certain allergy for commitment, intervention and clarity, the meaning of globalisation has become ever more loaded with few other hazy and problematic conceptual idioms. One obvious disjuncture is when the term "global" is uttered, it often means the EuroAmerica, plus Japan. It is not uncommon when this euphoria for being global has ironically cause an aversion to anything that is local and regional. This warrants our full criticism as the exclusive idea of being global reflects at its heart the predominance of the captive mind in our midst. ${ }^{20}$

Some scholars like Clive Kessler would see that possibility that the very idea of "good" globalisation where the thrust of universalism is at the center stage. While Kessler noted that the criticism and scepticism on globalisation is warranted, the very idea of universalism engendered in globalisation could well contain some positive dimensions. He opines:

"Yet, against this negative assessment of what globalization may mean for the creation of one single integrated human community, we should not be insensitive to the possibility of a positive potential of truly historic significance for humankind within the now breakneck rush of the globalization process... Whether it takes the form we may prefer or not, globalization processes are arguably now creating, for the first time in human history, the detailed social infrastructure of a single unified humanity, a universal human community: a network of mutual human interdependence and of worldwide involvement in one another's fate. It may, at worst, be the interdependence born merely of market principles, of those who have long dreamed of a world held together

19 Mansour opines: “Umat Islam, terutama kelompok miskin tertindas, di era globalisasi kapitalisme akan menghadapi gelombang pemiskinan structural yang belum pernah mereka alami sebelumnya. Kalau begitu Golongan muslim miskin itu membutuhkan teologi, paradigma dan analisis sosial yang memihak pada mereka, itulah teologi bagi kaum tertindas, teologi yang membebaskan mereka dari ketertindasan dan eksploitasi global." Mansour Fakih, "Islam sebagai Alternatif,", p xviii

20 Syed Hussein Alatas, “The Captive Mind and Creative Development' in Seah Chee-Meow, (ed.) Asian Values and Modernization. (Singapore University Press, 1977) 
by nothing more noble than the dismal logic of comparative advantage in production. But, even in this worst case, what is emerging nonetheless is a comprehensive form of human interdependence, unprecedented in its scope and grip."${ }^{21}$

Indeed for some writers, there can be a globalisation without neoliberalism. Wim Dierckxsens, calls for citizen-based globalization, where the common good is secured, where "private interests would be allowed to operate but not at the expense of the common good or the citizenry." ${ }^{22}$

\section{Education and Globalisation}

We need critical education for the young to prepare them to understand the dynamics of the global order, comprehending the present and impending crises if the current challenges are not addressed seriously. Our students must be prepared to know the challenges of globalisation; to simply dismiss it as Western would mean that miss a serious point. Conversely, to embrace it confidently without a critical posture is a sheer naivety. To be globally conscious via critical education is therefore imperative. Our young must be given a global outlook, but definitely a non-parasitical one, nor timid to their own national and regional traditions; with the ability to see that the predicament of the international communities are interrelated, without being timid to first address the problems at their home ground.

The dangerous effects of globalisation on the academic and intellectual outlook must be our concern and priorities. Masao has reflected critically on this point, especially the position of university under the hegemonic dominance of global neoliberalism which brought about corporatisation of the university. As universities eager in its global ranking, it turns into a corporate like organisation where "the faculty_ of either private or public universities, which are only superficially distinct from each other - are now corporate employees who

21 Clive S Kessler, "Globalization: another false universalism," Third World Quarterly, Vol. 21, No.6, 200o, p. 939

22 Wim Dierckxsens, The Limits of Capitalism: An Approach to Globalization without Neoliberalism. (London: Zed Books, 2000), 143 . 
can be underemployed, outsourced and displaced. Corporatism can banish whomever it finds undesirable as well as unproductive." ${ }^{23}$

Henry Giroux who has written consistently and persistently on this subject points to the problems of corporatisation of the education system, especially the universities, reiterates this point cogently:

"The corporatization of schooling and the commodification of knowledge over the last few decades have done more than make universities into adjuncts of corporate power. They have produced a culture of critical illiteracy and further undermined the conditions necessary to enable students to become truly engaged, political agents. The value of knowledge is now linked to a crude instrumentalism, and that only mode of education that seems to matter is that which enthusiastically endorses learning marketable skills, embracing a survival-of-the-fittest ethic, and defining the good life solely through accommodation and disposal of the latest consumer goods. Academic knowledge has been stripped of its value as a social good. To be relevant, and therefore adequately funded, knowledge has to justify itself in market terms or simply perish. ${ }^{24}$

In short, students, including educators, need to be wary of the zeal and enthusiasm to embrace the globalisation, which takes in the form of "global campus" and "global ranking," where university's corporatisation drivesis gaining momentum everyday. In particular, the impact of Globalisation on institutes of higher learning is one case in point that we cannot afford to ignore. The critical discussions by some thinkers on this subject deserve to be given attention. Masao noted the effects of globalisation via the infiltration of corporatism in the academia. No universities are spared, from developing to developed nations. In the case of Japanese universities, he observed this:

"In literature, arts, and intellectual discourse, politics has now been carefully avoided in defense of the status quo, and hard subjects have been eagerly replaced with "soft" consumer topics. Intellectual rigor is visibly being compromised. Extreme colloquialism, nonparagraphic and nonsyntatic structure, and neologism, especially foreign words, have affected even academic writing style. References have been reduced to a casual minimum,

23 Masao Miyoshi, "Sites of Resistance in the Global Economy," p. 78

24 Henry A Giroux, Neoliberalism's War on Higher Education. (Chicago: Haymarket Books, 2014), 69. 
removing the possibility of constructing a discursive system. Instead of substantive and coherent writing, conversations conducted by a group of "writers" are transcribed, edited, and printed...[this] has been the dominant mode of discourse.... Although political discourse has not entirely vanished, it is usually conducted in abstruse abstractions. Thus there is seldom a serious argument, and only rarely do we find well-documented and closely reasoned assertions or refutations. The development of bibliography and book review, too, is minimal. Most journals of opinion have vanished, and those remaining are packed with disjointed gossip and random judgments. Of course, the general disarray of intellectual discourse is perhaps worldwide as a function of intensified consumerism and neoliberalism." ${ }^{25}$

In sum, we should aim to nurture intelligentsia for the present and future who can see themselves as responsible citizens of their respective nation states, but who are equally committed and have interest in the plight and predicaments of other nations. In the discursive realms, writers from the critical literacy circles have given much attention of the effects of globalisation to society and education in particular. This is one area of discursive platform that we need to give attention while addressing and engaging the challenges of globalisation. As advocated in the critical pedagogical discourse, we need:

"Education for personal, social, and environmental sustainability should therefore be humanizing, fomenting solidarity and empowering community. For this it has to face the historical fatalism of market ideology that preaches the radical extreme individualism and competitiveness that is directly opposed to humanization and solidarity, interpreting the latter as charity and philanthropy. The neoliberal fatalism needs the "mechanization" and "technification" of human beings and the weakening or destruction of the community; it is essentially fragmentary, disruptive, and dissociative." ${ }^{26}$

\section{A Humanised Global Integration}

If the present globalised order is characterised by its dehumanised effects, we need to create and project another kind of globalisation which points to a

\footnotetext{
25 Masao Miyoshi, "The University and the "Gloval" Economy: The Case of the United States and Japan," The South Atlantic Quarterly, 99, 4, 2000, p. 677

26 Walter Ferreira de Oliveira, "For a Pedagogy of Solidarity," p. 8o
} 
humanised global integration. In essence, a humanised globalisation cherishes the ideals of universality, with deep empathy for particularity. Solidarity and cooperation should be the mantra in the humanised global integration. A humanised integration, a truly human solidarity is not an impossibility nor utopianistic. The global outlook that we should embrace is one that is truly universal, one that is humanistic, with humanitarian practices and ideals. Also the celebration of the universality has no meaning if we do not have the nuances of the particular. Most importantly, to be critical does not mean to surrender to hopelessness. While having hope we cannot the deluded by utopianism.

It is in this sense that it is important to critically reflect the condition of a dehumanised order, say under the hegemonic globalisation, before we enthusiastically annunciate the importance of a humanised global order. Walter Ferreira de Oliveira succinctly, following Paulo Freire, wrote that the condition of dehumanisation, where it has become widespread and entrenched in a society

"through radical stimulus to competitiveness between people who see themselves as potential adversaries or as potential means for achieving each other's objectives. Relations are to be based on fear, suspicion, and material interest this existential proposal clearly manifested in the workplace and often repeated in propaganda from other socio-pedagogical environments causes hopelessness and loss of meaning in life for many. This can be worse for those whose social and economic position is more vulnerable, those whose vicissitudes and precarious levels of "disempowerment" hinder the establishment of social and psychological need to overcome this brutal reality." ${ }^{\prime 27}$

We are in need of a humanised global order where in such humanism, it is inscribed, in the words of Edward Said, "the final resistance we have against the inhuman practices and injustices that disfigure human history." ${ }^{28}$ Indeed as the world is becoming much closer via the mass media, where the democratic access enable us to see the predicaments of the others in other

\footnotetext{
27 Ibid.,pp. 73-74

28 Edward Said, "Worldly Humanism versus Empire Builders," in Barry F. Seidman and Neil J. Murphy (eds.) Toward a new political humanism. (Amherst, NY: Prometheus Books, 2004), 313.
} 
parts of the world, infusing a sense of solidarity against all kinds of abuses, extremism, injustices and the like. This would not be possible, "were it not for the existence of alternative communities all across the world, informed by alternative information, and keenly aware of environmental, human rights, and libertarian impulses that bind us together in this tiny planet."29

A global, universal outlook obviously could mitigate against our own intellectual insularity, parochialism and ambivalence. In that sense we need such cultural and intellectual globalisation informed by the creative blending of the endogenous and exogenous intellectual traditions. We know today Muslims societies are facing tremendous problems in the post-war era, where foreign military intrusions, sectarian strife and civil wars, underdevelopment, political corruption and authoritarianism, as well as environmental degradation. An affirmation of a humanised global integration is the way to go where the respect and the recognition of the dignity and rights of the person, the respect of fellow co-religionists and the larger humanity becomes part of our ethical compass. In sum, our future entails:

(1) The ability to forge progressive outlook to create a better society that could guarantee freedom, social justice, development and progress, at the level of individual and collective level

(2) The ability to be autonomous, in all realms of life, be it in our political and economic life, social and cultural, educational and intellectual, without being captive or dependent.

(3) The ability to maintain peace and stability, with disengagement of conflicts and animosity, where the thrust for mutual cooperation, coexistence and democratic ethos prevail.

(4) The ability to protect and safeguard the environmental condition, where the climatic change and environmental degradation is endangering the living species.

\section{Conclusion}

While some others would point to reaping the economic opportunities of globalisation, this paper points to the need to discuss beyond the preoccupation of economic needs. The real opportunity is when we are able to see the problems of humankind as a whole, a truly belonging to a common humanity. Building

29 Ibid., p. 313 
solidarity at a global scale, especially in the Third World must be our concern. Muslims, like all communities and peoples in this planet, could not afford to live in isolation, maintaining their exclusivity in order to preserve their authenticity. That was never the vision of the Quran.

It is this context of a globalised world that enabled us to have closer access to each other, amongst the Muslims umma, and the larger humanity. Muslims must be at the forefront in forging human solidarity and cooperation so as to attain a humanised global order. We must embrace in great conviction of the Quranic injunction to compete for good amongst the diverse nations in the world. Also the Muslim world cannot submit to the tendency to say that we have our own globalisation way, or Islamic way of globalisation. Such tendency will only acerbate our own parochialism and marginality.

Most importantly, our embracement of the idea of globalisation cannot be simply in economic term, or harnessing and reaping its economic opportunities. Such thinking is naïve, because we have not scrutinised the very structures in the process of globalisation. We could and should obviously take advantage of the opportunities only after we are able to comprehend the workings of globalisation under the present economic order. As long as we remain only in the consuming end, and the supplier of basic commodities, we will not be the actor in this globalisation. As long as we allow our own economy only to be platform for resources and market for the TNCs, it could only detrimental for own in the present and the future.

Hence, our response to globalisation should therefore be a dialectical one, invariably weighing its possibilities and limitations, with criticality and hope, without succumbing to pessimism nor captivation. As one Indonesian scholar puts it aptly:

"Globalisasi adalah sebuah kenyataan yang tidak bisa dihindari. Untuk itulah diperlukan keberanian untuk merespon, bukan justeru lari menjauhi, apa lagi menghindarinya dengan mengkritik, mencela, atau bahkan mencaci maki. Langkah untuk meresponsnya pukan sekedar defensive (bertahan), akan tetapi ofensif, bahkan juga progresif." ${ }^{30}$

30 Qodri Azizy, Melawan Globalisasi: Reinterpretasi Ajaran Islam, Persiapan SDM dan Terciptanya Masyarakat Madani. (Yogyakarta: Pustaka Pelajar, 2003). 
To conclude: An Indonesia poet Acep Zamzam Noor once remarked in a beautiful but a cynical line which says: "Ada banyak cara/ untuk memulihkan ekonomi /Salah satunya/ menjual hati nurani." That certainly warrant to be articulated in as much we can further it, in line with our topic and concern, namely:"Ada banyak cara/ untuk memulihkan globalisasi/Salah satunya/ pemberdayaan dengan berani.” 
162 - 164 | Azhar Ibrahim, Muslim World and the Globalisation Challenge

\section{Reference}

Arief, Sritua. Negeri Terjajah:Menyingkap Ilusi Kemerdekaan. Yogyakarta: Resist Book, 2006.

Azizy, Qodri. Melawan Globalisasi: Reinterpretasi Ajaran Islam, Persiapan SDM dan Terciptanya Masyarakat Madani. Yogyakarta: Pustaka Pelajar, 2003.

Barry F. Seidman and Neil J. Murphy (eds.). Toward a new political humanism. Amherst, NY: Prometheus Books, 2004.

Baswir, Revrisond. Bahaya Neoliberalisme. Yogjakarta: Pustaka Pelajar, 2009. Chomsky, Noam. Profit Over People: Neoliberalism and Global Order. New York: Seven Stories Press, 1999.

Dahana, Radhar Panca. Ekonomi Cukup:Kritik Budaya pada Kapitalisme.Jakarta: Kompas, 2015 .

Dierckxsens, Wim. The Limits of Capitalism: An Approach to Globalization without Neoliberalism. London: Zed Books, 2000.

Drilik, Arif. The End of Colonialism? The Colonial Modern in the Making of Global Modernity. Boundary 2, 32:1, 2005.

Fakih, Mansour. Runtuhnya Teori Pembangunan dan Globalisasi. Yogjakarta: Pustaka Pelajar \& Insist Press, 2008.

Fakih, Mansour.Jalan Lain: Manifesto Intelektual Organik. Yogyakarta: Pustaka Pelajar, 2011.

Freire, Paulo. Pedagogy of Solidarity. California: Left Coast Press, 2014.

Giroux, Henry A. Neoliberalism's War on Higher Education. Chicago: Haymarket Books, 2014.

Hussin, Rosazman, et al. Globalisasi: Beberapa Pendekatan Sains Sosial. Kuala Lumpur: DBP, 2001.

Kessler, Clive S. Globalization: another false universalism, Third World Quarterly, Vol. 21, No.6, 2000.

Miyoshi, Masao. Sites of Resistance in the GlobalEconomy. Boundary 2, 22:1, 1995. Miyoshi, Masao. The University, the Universe, the World, and "Globalization. The Global South, Vol. 1, 1, 2007. 
Miyoshi, Masao. The University and the "Gloval" Economy: The Case of the United States and Japan. The South Atlantic Quarterly, 99, 4, 2000.

Musa, M Bakri. Malaysia in the Era of Globalization. San Jose: Writers Club Press, 2002.

Nugroho, Tarli. Polemik Ekonomi Pancasila. Yogyakarta: Mubyarto Institute, 2016.

Prasetyo, Eko. Islam Kiri:Jalan Menuju Revolusi Sosial. Yogyakarta: Insist Press, 2004.

Prasetyo, Galih. Indonesia dalam Cengkraman Liberalisme: Krisis, IMF dan Jalan Pemulian Ekonomi. Jakarta: Penerbit Koekoesan, 2015.

Prasetyo, Eko. Islam Kiri Melawan Kapitalisme Modal dari Wacana Menuju Gerakan. Yogyakarta: Pustaka Pelajar \& Insist Press, 2002.

Seah Chee-Meow, ed. Asian Values and Modernization. Singapore University Press, 1977.

Wahid, Abdurrahman. Islamku, Islam Anda, Islam Kita. Jakarta: The Wahid Institute, 2006. 